\title{
正弦波空気振動を利用した薄板の動的材料試験法†
}

\author{
山本嚴・横川忠晴 \\ 金属材料技術研究所 東京都目黒区中目黒 2-3-12 \\ (昭和 47 年 1 月 21 日 受付)
}

\section{Dynamic Testing Method for Thin Plate with Sinusoidal Pneumatic Excitation}

\author{
Iwao Yamamoto and Tadaharu Yokogawa \\ (National Research Institute for Metals, Meguro-ku, Tokyo) \\ (Received January 21, 1972)
}

\begin{abstract}
A testing method for the elasticity of thin metal plate with thickness less than $0.3 \mathrm{~mm}$ is described. A specimen is held as a cantilever of which free end is centered between two symmetrically set nozzles. The specimen oscillates by the push-pull air jet pressure from the nozzles. The pressure forces are obtained from a two-phase pneumatic oscillator consisting of a motor driven rotary disk having its surface inclined to the rotating plane and two nozzles which are put on the same plane near the surface of the disk. By changing the angular velocity of the disk, the specimen is made to resonate. The Young's modulus of the specimen can be estimated by observing the resonant frequency. The testing method is also applicable to fatigue test of thin plates. Compared with the conventional method, this testing method has the merit that neither attachment nor special machining is needed on the specimen regardless of specimen materials. The testing method would be also applicable to such non-metalic soft materials as paper and plastics.
\end{abstract}

1. 序言

電子機器や精密計器用として各種のばね材料が開発 され使用されてきているが，炎の弾性的性能を正確か つ容易に測定することは, 弾性材料の開発研究, なら びにその製造過程での品質管理のら觉から特に重要で 两る。材料のばね特性の測定法としては，従来各種の 方式が提案されそれに基づく測定機が製作されてきた が, 電子機器や精密計器用に用いられる $0.3 \mathrm{~mm}$ 以下 といらよらな極く薄い板状材料を対象とする場合を考 えると, 従来の形式のものは取り扱い易さ之精度の点 で必ずしも十分であるとはい光ないたと党ば，薄板 の縦弹性係数測定法として知られている JIS の片持梁 方式” DIN の Euing の方法を基礎とする方式” は, 極薄板特有の極端な可撓性のため, 試料支持や荷 重の加兄方の影響をう沙易く, またたわみ量の測定の

†第13 回自動制御連合講演会で発表 (昭 45·10)
さいに誤差を生じ易いまた，動的測定法では，板の 横曲げ共振法は薄板や棒のヤング率測定法として最も 適したもの之考兄られ, 古くからこれに基づく測定法 が行なわれているが3) 6), 電磁的汇試料を励振するた め試料に付着させる磁性体が必要であり,さらにその ためによって生ずる質量ならびに励振磁場との相互作 用（試料の運動に伴う誘起電力効果，らず電流ならび にヒステリシス効果）による補正を行なわなければな らず，そのら元試料が強磁性体の場合には磁場による 弾性係数の变化の影響も考虑汇加兄なければならない。 ここで提案する測定法は，横曲げ振動法に基づく薄 板の弾性特性測定法でめるが，試料を従来のもののご とく電磁的でなく，対称的に配置されたノズルからの 正弦波状に変化する空気の噴流力により励振させ上う とするるのである，特徴とするところは，試料が磁性 体であるなしにかか和らず試料になんらの加工や付加 質量を加兄ることなく金属薄板の弾性係数を測定でき 
ること, 疲労試験も行ないらること, さらに紙やプラ スチックなどの非金属材料の弾性的特性試験への応用 が考えられる点にある。

\section{2. 正弦波状空気圧による薄板試料励振法}

正弦波状空気圧力による試料励振法の原理図を Fig.

1 に示す。ここで，円板 D怕回転軸に垂直な平面にわ

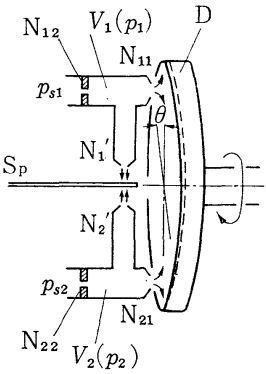

$\mathrm{N}_{1}{ }^{\prime}, \mathrm{N}_{2}{ }^{\prime}, \mathrm{N}_{11}, \mathrm{~N}_{21}$ : nozzle

$\mathrm{N}_{12}, \mathrm{~N}_{22}$ : orifice

$\mathrm{D}:$ disk

$\mathrm{S}_{\mathrm{p}}$ : specimen (thin bar)

(a)

Fig. 1 Schematic diagram of pneumatic fixed free bar vibrating method

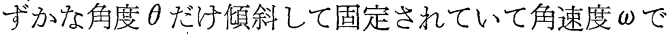
回転している。ノズル $\mathrm{N}_{11}, \mathrm{~N}_{21}$ は円板の直径上にその 表面に近接して取りつけられていて，それぞれ，才り フィス $\mathrm{N}_{12}, \mathrm{~N}_{2}$ と組合わされて空気マイクロメータ単 一回路を形成している，D が回転するにつれて， $\mathrm{N}_{11}$ 特よび $\mathrm{N}_{21}$ とそれらに対向する D の表面との間隔が 正弦波状に変化し7)，それぞれの背圧室 $\mathrm{V}_{1}$ 物よび $\mathrm{V}_{2}$ の圧力が互いに $180^{\circ}$ 位相がずれて正弦波状に変動す る.ノズル $\mathrm{N}_{1}{ }^{\prime}$ ならびに $\mathrm{N}_{2}{ }^{\prime}$ はノズル $\mathrm{N}_{11}, \mathrm{~N}_{21}$ に 比べて小口径のノズルで，片持ら梁状に保持された試 料片を間にはさみ，これに垂直な直線上に配置されて いる. 1 個の励振用ノズルから試料に加えられる力 $F$ は背压 $p$ と励振用ノズルと試料との間隔 $x$ との関数之 して,

$F=F(p, x)=F\left(p_{0}, x_{0}\right)+\left(\frac{\partial F}{\partial p}\right)_{p_{0}} \Delta p+\left(\frac{\partial F}{\partial x}\right)_{x_{0}} \Delta x$

であらわされるから，Fig. 1 の配置では 2 つ励振 ノズルからの合計の励振力 $F_{t}$ はノズル $\mathrm{N}_{11}, \mathrm{~N}_{12}$ それ ぞれに対応する添字 1,2 を用いて,

$$
\begin{aligned}
F_{t}= & F_{1}\left(p_{01}, x_{01}\right)-F_{2}\left(p_{02}, x_{02}\right) \\
& +\left\{\left(\frac{\partial F_{1}}{\partial p_{1}}\right)_{p_{01}} \Delta p_{1}-\left(\frac{\partial F_{2}}{\partial p_{2}}\right)_{p_{02}} \Delta p_{2}\right\} \\
& +\left\{\left(\frac{\partial F_{1}}{\partial x_{1}}\right)_{x_{01}} \Delta x_{1}-\left(\frac{\partial F_{2}}{\partial x_{2}}\right)_{x_{02}} \Delta x_{2}\right\}
\end{aligned}
$$

となる.ここで, $p_{01}, p_{02}, x_{01}, x_{02}$ ：作動中心に打ける $p_{1}, p_{2}, x_{1}, x_{2}$ であり, $\Delta p_{1}, \Delta p_{2}, \Delta x_{1}, \Delta x_{2}: p_{1}, p_{2}, x_{1}, x_{2}$ の 作動中心からの変動分とする.（2）式を用いて試料 片に関する運動方程式をつくると， $\Delta x_{1}=-\Delta x_{2}=\Delta x$ として, 次式が得られる。

$$
\begin{aligned}
M \frac{d^{2} \Delta x}{d t^{2}} & +D \frac{d \Delta x}{d t}+\left[K_{s}-\left\{\left(\frac{\partial F_{1}}{\partial x}\right)_{x_{01}}+\left(\frac{\partial F_{2}}{\partial x}\right)_{x_{02}}\right\}\right] \Delta x \\
& =\left\{F_{1}\left(p_{01}, x_{01}\right)-F_{2}\left(p_{02}, x_{02}\right)\right\} \\
& +\left\{\left(\frac{\partial F_{1}}{\partial p_{1}}\right)_{p_{01}} \Delta p_{1}-\left(\frac{\partial F_{2}}{\partial p_{2}}\right)_{p_{02}} \Delta p_{2}\right\}
\end{aligned}
$$

ここで, $M$ : 試料片の等価質量, $D$ : 同じく等価減衰 係数, $K_{S}$ : 同じく等価ばね定数で, 上式右辺第 1 項は 試料に加えられる力の静的な成分，第 2 項は励振力の 成分をあらわす，第 2 項はさらに，

$$
\begin{aligned}
& A=\left(\frac{\partial F_{1}}{\partial p_{1}}\right)_{p_{01}}\left(\frac{d p_{1}}{d h_{1}}\right)_{h_{01}} r_{1} \tan \theta, \\
& B=\left(\frac{\partial F_{2}}{\partial p_{2}}\right)_{p_{02}}\left(\frac{d p_{2}}{d h_{2}}\right)_{h_{02}} r_{2} \tan \theta
\end{aligned}
$$

を用いて，

$$
F_{t 2}=(A+B) \cos 2 \pi f t
$$

とあらわすことができる．ここで， $r_{1}, r_{2}: \mathrm{N}_{11}, \mathrm{~N}_{21}$ の 円盤 $\mathrm{D}$ の心心ららの距離, $\theta$ : 円盤の傾斜角度, $h_{01}$, $h_{02}$ : 作動中心に対する円盤と $\mathrm{N}_{11}, \mathrm{~N}_{21}$ との間隔であ る.

i ） $\mathrm{N}_{1}{ }^{\prime}$ と $\mathrm{N}_{2}{ }^{\prime}$ を同一寸法のノズルとし， $r_{1}=r_{2}$, $x_{01}=x_{02}, p_{01}=p_{02}$ とすれば，（3）式の右辺第 1 項は 0 となり，試料は励振力のないときの静止点を中心とし て振動することになる. いま励振周波数 $f$ を変化させ て試料の振幅が最大となる周波数を求め，これを $f_{r}$ と すれば,

$$
\begin{gathered}
f_{n}^{\prime}=\sqrt{\left[K_{s}-\left\{\left(\frac{\partial F}{\partial x}\right)_{x_{01}}+\left(\frac{\partial F}{\partial x}\right)_{x_{02}}\right\}\right] / M} \\
\doteqdot f_{n}\left\{1-\frac{F_{x}}{2 K_{s}}-\frac{F_{x}^{2}}{8 K_{s}^{2}}-\frac{F_{x}{ }^{\prime 2}}{16 K_{s}{ }^{3}}\right\} \\
\zeta^{\prime}=\frac{D}{2 \sqrt{M K_{s}\left(1-\frac{F_{s}}{K_{s}}\right)}} \\
\doteqdot \zeta\left\{1+\frac{F_{x}}{2 K_{s}}+\frac{3}{8}\left(\frac{F_{x}}{K_{s}}\right)^{2}+\frac{5}{16}\left(\frac{F_{x}}{K_{s}}\right)^{3}\right\} \\
F_{x}=\left\{\left(\frac{\partial F}{\partial x}\right)_{x_{01}}+\left(\frac{\partial F}{\partial x}\right)_{x_{02}}\right\} \\
f_{n}=\sqrt{\frac{K_{s}}{M}}, \quad \zeta=\frac{D}{2 \sqrt{M} \bar{K}_{s}}
\end{gathered}
$$

が成りたつ。ここで $f_{n}^{\prime}, \zeta^{\prime}$ はこの振動機構に打ける 試料片の固有振動数ならびに減衰比, $f_{n}, \zeta$ は試験片単 独の場合の固有振動数ならびに減衰比である.

$f_{n}$ と試料片の縦弾性係数 $E$ との間には,

$$
E=\frac{4 \pi^{2} l^{4} A f_{n}^{2}}{\lambda^{4} I g}
$$




$$
=\frac{48 \gamma \pi^{2} f_{n}^{2} l^{4}}{g h^{2} \lambda^{4}} \text { (一様な矩形断面の場合) }
$$

の関係が成り立つことが知られて物り ${ }^{5\rangle, 6) ， い ま ~} F_{x} \ll$ $K_{s}$ とすれば,（6)，(7) 式から $f_{n}^{\prime} \simeq f_{n}, \zeta^{\prime} \simeq \zeta$ とな り,さらに $\zeta \ll 1$ のように選べば（5）式から $f_{r} \simeq f_{n}$ 峸りたつので，(10) 式を用いて $f_{n}^{\prime}$ を測定するこ そから試料の縦弾性係数Eを求めることができる。こ こで, $\gamma$ : 試料片の比重量, $A$ : 断面積, $I$ : 断面 2 一次モーメント, $h:$ 板の厚み, $l$ : 長さ, $g$ :重力の 加速度, $\lambda$ ：境界条件と振動形による定数 (1.875 (1 次)）たとえば，口径 $0.5 \mathrm{~mm}$ のノズルを使用して長 さ $8 \mathrm{~cm}$, 幅 $3 \mathrm{~mm}$ ，厚久 $0.3 \mathrm{~mm}$ の燐青銅板を振動 させた場合， $F_{x}=0.0042 \mathrm{~g} / \mathrm{mm}, K_{s}=0.48 \mathrm{~g} / \mathrm{mm}, \zeta^{\prime}$ $:=0.015$ となる。

ii） $x_{01}$ と $x_{02}$ ならびに $p_{01}$ と $p_{02}$ を所要の值に 選べば，（3）式の右辺第 1 項を特定の值として試料 片に一定力を加光，また，(4) 式の $A ， B$ を別個に 選ぶことによって所要の振幅で振動させることができ る.この応用としては, 試料片を荷重負荷の状態での 疲労試験やばね限界值試験が考光られる。

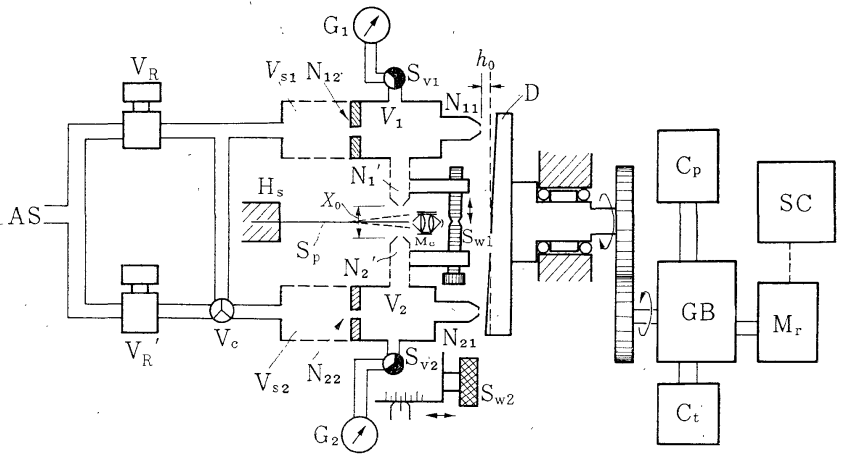

AS : air source

$\mathrm{V}_{\mathrm{R}}, \mathrm{V}_{\mathrm{R}}$ ' : pressure control valve

$\mathrm{S}_{\mathrm{v} 1}, \mathrm{~S}_{\mathrm{v} 2}:$ valve

$\mathrm{V}_{\mathrm{c}}: 2$ way valve

$\mathrm{N}_{12}, \mathrm{~N}_{22}$ : fixed orifice

$\mathrm{N}_{11}, \mathrm{~N}_{21}$ : nozzle

$\mathrm{N}_{1}{ }^{\prime}, \mathrm{N}_{2}{ }^{\prime}$ : nozzle

$\mathrm{S}_{\mathrm{w} 1}:$ micrometer screw

$\mathrm{S}_{\mathrm{w} 2}:$ micrometer screw

GB : gear box

$P$ : disk with inclined surface plane

$\mathrm{V}_{\mathrm{s} 1}, \mathrm{~V}_{\mathrm{s2}}$ : constant pressure chamber

$\mathrm{V}_{1}, \mathrm{~V}_{2}$ : air chamber

$\mathrm{C}_{\mathrm{p}}$ : frequency counter

$\mathrm{C}_{\mathrm{t}}$ : total account counter

$\mathrm{M}_{\mathrm{r}}$ : servo moter

$\mathrm{G}_{1}, \mathrm{G}_{2}$ : pressure gauge

$\mathrm{H}_{\mathrm{s}}$ : specimen holder

SC : motor speed controller

$\mathrm{M}_{\mathrm{c}}$ : measuring microscope

$\mathrm{S}_{\mathrm{p}}$ : specimen

Fig. 2 Schematic diagram of the testing apparatus

\section{3. 正弦波状空気圧力による薄板励振装置}

\section{$3 \cdot 1$ 試作装置}

Fig. 2 は Fig. 1 の原理に基づき，2.（i ),（ii）の 試験を行ないらることを目的として試作された装置の 構造である.ここで, 制御回路 SC で速度制御された モータ $M_{\mathrm{r}}$ は歯車列 $\mathrm{GB}$ をへて，表面が回転軸に垂
直な平面に対し $\theta$ だけ傾斜した円盤Dを所要の速度で 回転させる.Dの回転数は瞬間回転数を $C_{p}$, 積算回 転数を $C_{t}$ により計数表示されるようになっている. ノズル $\mathrm{N}_{11}, N_{21}$ はそれぞれ室 $\mathrm{V}_{1}, \mathrm{~V}_{2}$ に固定されてい て，円盤 D の回転中心軸を通って微動ねじ $\mathrm{S}_{\mathrm{w} 2}$ によ り水平方向に移動することが可能である.ノズル $\mathrm{N}_{1}{ }^{\prime}$, $\mathrm{N}_{2}{ }^{\prime}$ はそれぞれ室 $\mathrm{V}_{1}, \mathrm{~V}_{2}$ に結合するように配管され ていて, 一対の正逆ねじをもつ微動機構 $\mathrm{S}_{\mathrm{w} 1}$ により, 保持具 $\mathrm{H}_{\mathrm{s}}$ にセットされた試料を中心として互いに接 近または離反することが可能で，これらのノズルと試 料間間隔を所要の值に設定できる. ねじ $\mathrm{S}_{\mathrm{w} 1}$ の支持 台は円盤Dの回転軸の方向に微動できるようなステー ジに取りつけられていて，その微動機構を調節するこ とによりノズル $\mathrm{N}_{11}, \mathrm{~N}_{21}$ と円盤D との間隔を所要の值 に選ぶことができる．切換え弁 $\mathrm{V}_{\mathrm{c}}$ は供給源室 $\mathrm{V}_{\mathrm{s} 2}$ を 同じく $\mathrm{V}_{s 1}$ に接続または切離すためのもので, $V_{s 1}, V_{s 2}$ の圧力は制御并 $V_{\mathrm{R}}$ により所要の一定圧に調整される ほか, 補助制御弁 $V_{\mathrm{R}}{ }^{\prime}$ を用いて打の抹の別個の一定圧 力に調整されることが可能である. 室 $\mathrm{V}_{1}$ ならびに $\mathrm{V}_{2}$ は切換光弁 $\mathrm{S}_{\mathrm{v} 1}, \mathrm{~S}_{\mathrm{v} 2}$ をへて圧力ゲージ $\mathrm{G}_{1}, \mathrm{G}_{2}$ に接続 されるようになっていて，これを使用して 室 $\mathrm{V}_{1}, \mathrm{~V}_{2}$ の作動中心圧力特よび変動圧力 振幅の確認ならびそ調整を行ならことが可 能である、試験方法は次のようにして行な われる：i）試験片を保持具 $\mathrm{H}_{\mathrm{s}}$ にとの自 由端がノズル $\mathrm{N}_{1}{ }^{\prime}$ と $\mathrm{N}_{2}{ }^{\prime}$ を結ぶ線上に位 置するように固定する，ii） $\mathrm{S}_{\mathrm{w} 2}$ により円 盤の基準面（表面の中心を通り回転軸に垂 直な平面）とノズルとの間隔 $h_{0}$ を選ぶ. iii） $\mathrm{S}_{\mathrm{w} 1}$ により $\mathrm{N}_{1}^{\prime}$ と $\mathrm{N}_{2}^{\prime}$ との間隔 $X_{0}$ を選ぶ. iv） $\mathrm{V}_{\mathrm{s} 1}$ と $\mathrm{V}_{\mathrm{s} 2}$ を結合し， $\mathrm{V}_{\mathrm{R}}$ に よりこれらの圧力を $1 \mathrm{~kg} / \mathrm{cm}^{2}$ に設定し, 円盤を低速回転して $V_{1}, V_{2}$ の作動中心圧 力敃よび変動圧力振幅を確認した後, $\mathrm{S}_{\mathrm{v} 1}$, $\mathrm{S}_{\mathrm{v} 2}$ を閉じる。 v ) SC により円盤の回転 数を変化させて試料を共振させ, $\mathrm{V}_{\mathrm{R}}$ の調 整により共振を確認できる最小值まで $\mathrm{V}_{\mathrm{s} 1}$ の圧力を下げ，そのときの共振点の周波数 をよみとる。ここで，共振点の確認は測定 顕微鏡 $\mathrm{M}_{\mathrm{c}}$ の鏡内に映ずる試験片自由端の振動振幅の 観測によっている。このよらにして得られた共振周波 数を用いて (10) 式から縦弾性係数を求めることがで きるが，上記操作 ii），iii），iv）を行ならためには， 空気圧発振機構（ノズル $\mathrm{N}_{1}^{\prime}$ を側路とするノズル $\mathrm{N}_{11}$ と円盤との間隙特よびオリフィス $\mathrm{N}_{12}$ とからなる空気 マイクロメータ回路）の特性和よび励振用ノズルの噴 
流力に対する，ノズルの背圧括よびノズルと試料片と の間吵との関係が明らかになっていなければならない。 次節以下に拈いてこれらの関係についてしらべた結果 をのべる。な扮，疲労試験を行なう場合には，“試験片 の共振周波数よりやや低い周波数で円盤を回転させ， 切断または弹性的劣化を生ずるのに要した回転数を積 算回転計 $\mathrm{C}_{\mathrm{t}}$ でよみとればよい。この場合，切換总弁 $\mathrm{V}_{\mathrm{c}}$ により $\mathrm{V}_{\mathrm{s} 1}, \mathrm{~V}_{\mathrm{s} 2}$ 飞別個の圧力を供給し, 試料学所 要のバイアスカを加えた状態で振動せしめることが可 能である。ここで， $\mathrm{N}_{11}$ または $\mathrm{N}_{21}$ のいずれかを精密 可変校りで置き換光れば一方の励振用ノズルをバイア ス力専用として用いることができる．Table 1 はこの 試作装置に使用するため用意されたノズル，オリフィ スの形状寸法であるが，ノズルは $\mathrm{N}-1, \mathrm{~N}-2$ が発振用， $\mathrm{N}-3, \mathrm{~N}-4$ が試料励振用，N-5 が固定バイアスカ加圧 用である。

Table 1 Dimension of pneumatic circuit component

\begin{tabular}{|c|c|c|c|c|c|}
\hline \multicolumn{5}{|c|}{ nozzle } & \multirow{8}{*}{$\underbrace{}_{-1=1}$} \\
\hline $\begin{array}{l}\text { notation } \\
\text { in Fig. } 2\end{array}$ & No. & $D_{11}$ & $D_{12}$ & $\delta_{1}$ & \\
\hline $\mathrm{N}_{11}$ & $\mathrm{~N}-1$ & 1.99 & 3.96 & 2 & \\
\hline $\mathrm{N}_{21}$ & $\mathrm{~N}-2$ & 2. 01 & 4.01 & 2 & \\
\hline $\mathrm{N}_{1}^{\prime}$ & $\mathrm{N}-3$ & 0.47 & 1. 02 & 2 & \\
\hline $\mathrm{N}_{2}^{\prime}$ & $\mathrm{N}-4$ & 0.48 & 1.01 & 2 & \\
\hline $\mathrm{N}_{2}{ }^{*}$ & $\mathrm{~N}-5$ & 1.06 & 1.93 & 2 & \\
\hline \multicolumn{5}{|c|}{ orifice } & \\
\hline $\begin{array}{l}\text { notation } \\
\text { in Fig. } 2\end{array}$ & No. & $D_{21}$ & $\mathrm{D}_{22}$ & $\delta_{2}$ & \multirow{3}{*}{$\begin{array}{l}\text { unit }[\mathrm{mm}]^{\prime} \\
\text { ' }\end{array}$} \\
\hline $\mathrm{N}_{12}$ & O-1 & 0.75 & 0.75 & 1.40 & \\
\hline $\mathrm{N}_{22}$ & $\mathrm{O}-2$ & 0.74 & 0.74 & 1.42 & \\
\hline
\end{tabular}

* nozzle for constant impression force to specimen

\section{$3 \cdot 2$ 発振用空気マイクロメー夕回路の特性}

空気圧発振機構の構成は，片側の回路についてみれ ば，空気マイクロメータ回路の測定ノズル $\mathrm{N}_{11}$ に並列 飞固定ノズル $\mathrm{N}_{1}{ }^{\prime}$ が付加されたものと考光られる。

したがって，静特性ならびに動特性をあらわす関係式 は次のように導くことができる。すなわち，ノズル $\mathrm{N}_{11}$ とノズル $\mathrm{N}_{1}{ }^{\prime}$ から流出する空気流の合計の重量 流量を $W_{1}$ ，オリフィス $\mathrm{N}_{12}$ を通過する空気の重量流 量を $W_{2}$ とすれば，各絞り部に括ける流れの状態が断 熱的湾化し，絞り部通過後再熱されて等温になると 仮定することにより，

$$
\begin{aligned}
& W_{1}=\frac{\pi\left(\alpha_{11} d_{11} h_{1}+\alpha_{1}{ }^{\prime} \frac{d_{1}{ }^{\prime 2}}{4}\right)}{\sqrt{R \tau}} \cdot P_{1} \cdot \psi_{1}\left(\frac{P_{a}}{P_{1}}\right) \\
& W_{2}=\frac{\alpha_{21} \pi d_{21}{ }^{2}}{4 \sqrt{R \tau_{s}}} \cdot P_{s} \cdot \psi_{2}\left(\frac{P_{1}}{P_{s}}\right)
\end{aligned}
$$

$$
\begin{aligned}
& \psi_{1}\left(\frac{P_{a}}{P_{1}}\right)=\sqrt{\frac{2 g \kappa}{\kappa-1}\left\{\left(\frac{P_{a}}{P_{1}}\right)^{2 / \kappa}-\left(\frac{P_{a}}{P_{1}}\right)^{(\kappa+1) / \kappa}\right\}}\left(\frac{P_{a}}{P_{1}} \leq 0.528\right) \\
& =\psi_{m}\left(=21.42 \mathrm{~cm}^{1 / 2} / \mathrm{s}\right) \\
& \psi_{2}\left(\frac{P_{1}}{P_{s}}\right)=\sqrt{\frac{2 g \kappa}{\kappa-1}\left\{\left(\frac{P_{1}}{P_{s}}\right)^{2 / \kappa}-\left(\frac{P_{1}}{P_{s}}\right)^{(\kappa+1) / \kappa}\right\}}\left(\frac{P_{1}}{P_{s}} \leq 0.528\right), \\
& =\psi_{m}
\end{aligned}
$$

となり, 連続の条件 $W_{1}=W_{2}$, 等温仮定 $\tau_{s}=\tau=\tau_{a}$ か ら,

$$
h_{1}=\frac{\alpha_{21} d_{21}{ }^{2}}{4 \alpha_{11} d_{11}} \cdot \frac{p_{s}}{p_{1}} \cdot \frac{\psi_{2}\left(\frac{P_{1}}{P_{s}}\right)}{\psi_{1}\left(\frac{P_{a}}{P_{1}}\right)}-\frac{\alpha_{1}^{\prime} d_{1}^{\prime 2}}{4 \alpha_{11} d_{11}}
$$

として静特性式が導かれる。ここで， $R$ : 気体定数， $\tau_{s}, \tau, \tau_{a}$ ：それぞれ供給源，指示室，大気の絶対温度， $d_{11}, \alpha_{11}$ : 発振ノズルの口径と流量俰数, $d_{21}, \alpha_{21}$ : 内 部オリフィスの口径と流量係数, $d_{1}{ }^{\prime}, \alpha_{1}{ }^{\prime}$ : 励振ノズル の口径と流量係数, $P_{a}$ : 大気圧, $P_{1}$ : 指示室の絶対圧 力, $P_{s}$ : 供給源の絶対圧力, $g$ : 重力の加速度, $\kappa$ : 比熱此, である. (15) 式はさらに, 励振ノズル $\mathrm{N}_{1}{ }^{\prime}$ がないとした場合の通常の空気マイクロメータの静特 性式,

$$
h_{1}^{*}=\frac{\alpha_{21} d_{21}^{2}}{4 \alpha_{11}{ }^{2} d_{11}} \frac{P_{s}}{P_{1}{ }^{*}} \cdot \frac{\psi_{2}\left(P_{1}^{*} / P_{s}\right)}{\psi_{1}\left(P_{\alpha} / P_{1}{ }^{*}\right)}
$$

を用い， $P_{1}=P_{1}^{*}$ として，

$$
h_{1}=\frac{\alpha_{11}^{*}}{\alpha_{11}} h_{1}^{*}-h_{1 k}
$$

のように表現することができる。ここで，

$$
h_{1 k}=\frac{\alpha_{1}{ }^{\prime} d_{1}{ }^{2}}{4 \alpha_{11} d_{11}}
$$

である. $h_{1}{ }^{*}$ は $\mathrm{N}_{1}{ }^{\prime}$ がないとした場合の $\mathrm{N}_{11}$ と対向 面との間隙で, $\alpha_{1}{ }^{*}, P_{1}{ }^{*}$ は同じく流量係数, 指示室圧 カである.

Fig. 2 の装置で，ノズル $\mathrm{N}_{11}$ に対し円盤 D を静止 させたをま移動台をずらせて $\mathrm{N}_{11}$ とDの表面との間隙 を変化させ，これに対する室 $\mathrm{V}_{1}$ の压力変化をよみと ることにより静特性曲線を求めた。 Fig. 3 (a)，（b ) はこの結果で, 供給源圧力 $P_{s}=2.0 \sim 0.05 \mathrm{~kg} / \mathrm{cm}^{2}$ の 場合の測定結果に併せて，ノズル $\mathrm{N}_{1}{ }^{\prime}$ を取り去って その取りつけ口を密閉した場合の静特性曲線が点線と して併記されている。な挍，これらの曲線は $\alpha_{11}{ }^{*}=$ $\alpha_{11}, \alpha_{1}{ }^{\prime}=\alpha_{11}$ として (17)，(15') 式から求めたもので ある。この結果より， $h_{1}$ がきわめて小である範团を除 けば，この系の静特性曲線は， $\mathrm{N}_{1}{ }^{\prime}$ を除いた場合の静 特性曲線を $\mathrm{N}_{1}$ と $\mathrm{N}_{1}{ }^{\prime}$ の口径比で決められる一定值 


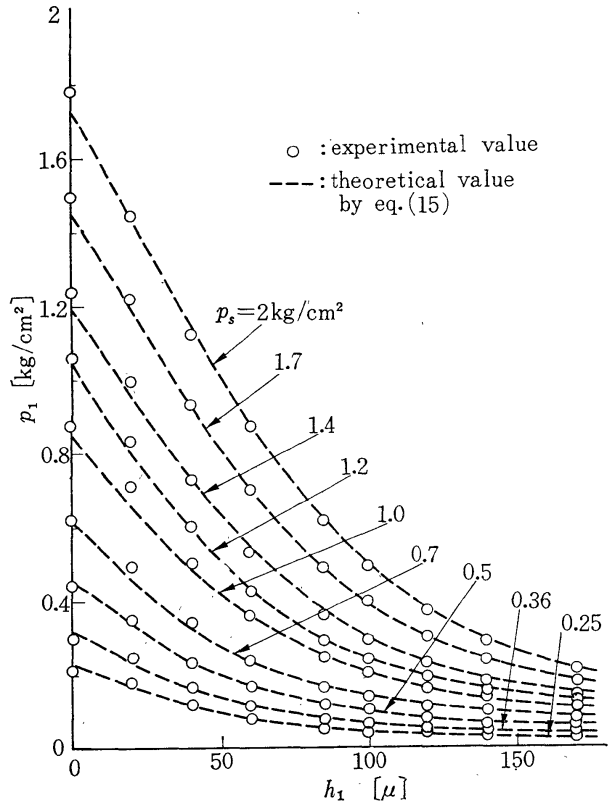

(a)

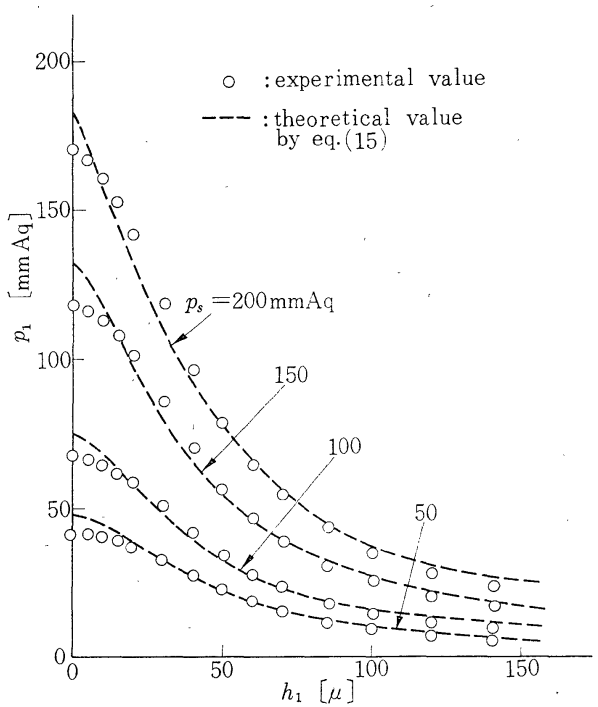

(b)

Fig. 3 Static characteristics of the pneumatic oscillator circuit

だけ横軸をずらせたものとして近似的に表現しらるこ とがわかる。

つぎに動特性に関しては， $\mathrm{N}_{11}$ ととの対向面との間 㩯ならびに $\mathrm{N}_{11}$ の背圧が一定值をとっている状態より， 対向面が急激に変化したとして微分方程式を求めるこ とから，この系が1次系として表現されることがわか るが，この場合の時定数,

$$
T_{s}=\frac{V_{T}}{R \tau_{a}} \frac{1}{\left\{\left(\frac{\partial W_{1}}{\partial P_{1}}\right)_{P_{1}}-\left(\frac{\partial W_{2}}{\partial P_{1}}\right)_{P_{1}}\right\}}
$$

は，(11)，(12) 式から $\frac{\partial W_{1}}{\partial P_{1}}, \frac{\partial W_{2}}{\partial P_{1}}$ を求めて (18) 式に代入することにより，

$T_{s}=$

$\frac{V_{T}}{\pi \sqrt{R \tau_{a}}\left\{\alpha_{11} d_{11} h_{1}\left(1+\frac{h_{1 k}}{h_{1}}\right) \beta\left(P_{a} / P_{1}\right)-\frac{\alpha_{21}}{4} d_{21}{ }^{2} \Gamma\left(P_{1} / P_{s}\right)\right\}}$

となる.ここで, $R$ : 気体定数, $V_{T}$ : 等価負荷容積で あり,

$$
\begin{aligned}
\beta\left(P_{a} / P_{11}\right)= & \sqrt{\frac{2 g \kappa}{\kappa-1}}\left\{\left(\frac{P_{a}}{P_{1}}\right)^{2 / \kappa}-\left(\frac{P_{a}}{P_{1}}\right)^{(\kappa+1) / \kappa}\right\}^{-1 / 2} \\
& \times\left\{\left(1-\frac{1}{\kappa}\right)\left(\frac{P_{a}}{P_{1}}\right)^{2 / \kappa}-\frac{\kappa-1}{2 \kappa}\left(\frac{P_{a}}{P_{1}}\right)^{(1 / \kappa)+1}\right\} \\
\Gamma\left(P_{1} / P_{s}\right)= & \sqrt{\frac{2 g \kappa}{\kappa-1}}\left\{\left(\frac{P_{1}}{P_{s}}\right)^{2 / \kappa}-\left(\frac{P_{1}}{P_{s}}\right)^{(\kappa+1) / \kappa}\right\}^{-(1 / 2)} \\
& \times\left\{\frac{1}{\kappa}\left(\frac{P_{1}}{P_{s}}\right)^{((2 / \kappa)-1)}-\frac{\kappa+1}{2 \kappa}\left(\frac{P_{1}}{P_{s}}\right)^{1 / \kappa}\right\}
\end{aligned}
$$

である。(19) 式をノズル $\mathrm{N}_{1}^{\prime}$ がない場合の通常の空 気マイクロメータ単一回路の時定数,

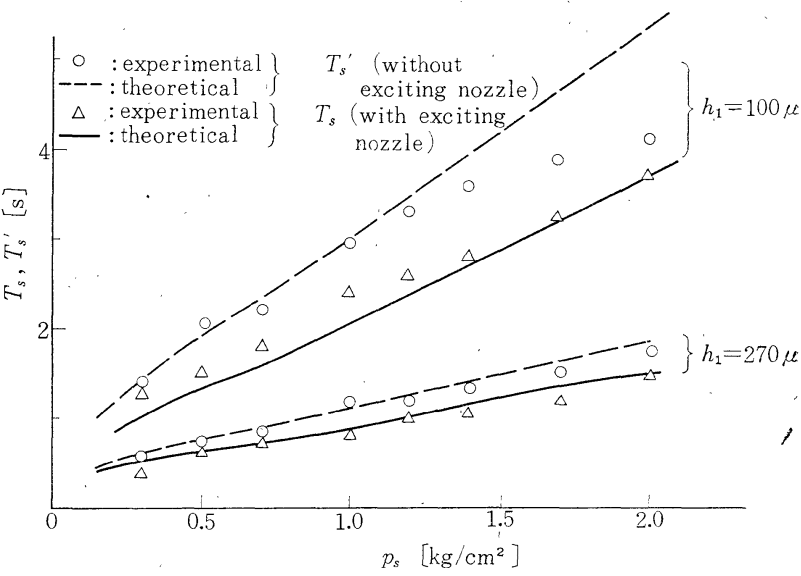

Fig. 4 Dynamic characteristics of the pneumatic oscillator circuit

$T_{s}^{*}=$

$$
\frac{V_{T}}{\pi \sqrt{R \tau_{a}}\left\{\alpha_{11} * d_{11} h_{1} * \beta\left(P_{a} / P_{1}^{*}\right)-\frac{\alpha_{21}}{4} d_{21}{ }^{2} \Gamma\left(P_{1}^{*} / P_{s}\right)\right\}}
$$

と比較すると， $\alpha_{11} \simeq \alpha_{11}$ * とすれば $h_{1}=h_{1}$ * としたと き, $h_{1}+h_{1 k}>h_{1} *,(15),(16)$ 式から $P_{1}^{*}>P_{1}$ で $\beta\left(P_{a} / P_{1}\right)>\beta\left(P_{a} / P_{1}^{*}\right),-\Gamma\left(P_{1} / P_{s}\right)>-\Gamma\left(P_{1}^{*} / P_{s}\right)$ と なるため $T_{s}^{*}>T_{s}$ となる。

Fig. 4 はステップ応答法により時定数を求めた結果 
である. 実験方法は，まず Fig. 2 の装置でノズル $\mathrm{N}_{11}$ の背圧室に付加容積 $760 \mathrm{~cm}^{2}$ を結合し, 静止させた円 盤Dに対してノズル $\mathrm{N}_{11}$ との間吵が所要の值 (Fig. 4 では $h_{1}=100 \mu$ ならびに $\left.h_{1}=207 \mu\right)$ になるように選 んだ.つぎに, 供給源を $0.2 \sim 2.0 \mathrm{~kg} / \mathrm{cm}^{2}$ の種々の圧 力に変化させ，その沶の誩のの場合について压力変化 が供給源ゲージ圧力の汪ぼ3\%になるよらに立上がり 時間 $0.2 \mathrm{~s}$ 以下の速度で移動台 ST にステップ状変 位をあた古, 出力空気圧変化を抵抗線丕計式圧力電流 変換器と記録計の組合せで記録した。ここで，STを ステップ状に変位させるには，歯車列，クラッチ，プ ーリからなる駆動機構を ST の調整ねじ $\mathrm{S}_{\mathrm{W} 2}$ に連結 し，これを手動により動かすことによった。このよう にして得られたオシログラムより，振幅の $63.2 \%$ の 到達時間をとって時定数としたものである。この場合 も，ノズル $\mathrm{N}_{1}{ }^{\prime}$ を取り除いた場合の実験結果が併せて 示されている. この結果より，時定数はノズル $\mathrm{N}_{1}{ }^{\prime}$ が 付加されない通常の空気マイクロメータ回路にくらべ て小となっていること，ならびに供給源圧力の上㫒と ともに減少することがわかる。な特，付加容積 760 $\mathrm{cm}^{3}$ を除いた場合の背圧室の容積は $1.0 \mathrm{~cm}^{3}$ であり, 実際の使用時の回路の時定数は，容積に比例するとし てこれらの值の $1 / 760$ になる。

ここで併記された曲線はそれぞれ（19），(20）式に よって計算して得たもので，この系の時定数が (19) 式によりかなりよく求纺らることがわかる。な捄 用したノズル，才リフィスは Table 1 の N-1， 0-1 でめる・

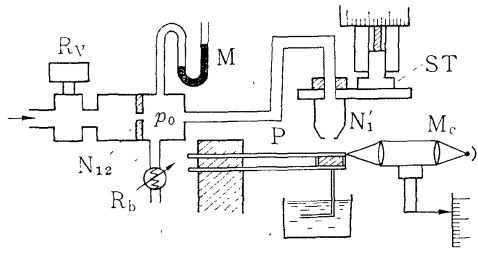
ST : movable stage
$\mathrm{R}_{\mathrm{b}}$ : slottle valve
$\mathrm{M}_{\mathrm{c}}$ : measuring microscope $\mathrm{P}$ : elastic plate
$\mathrm{M}:$ manometer
$\mathrm{N}_{1}^{\prime}$ : nozzle
$\mathrm{R}_{\mathrm{v}}$ : pressure regulator
$\mathrm{N}_{12}$ : orifice

Fig. 5 Experimental setup to measure the pressure force of the exiting nozzle

\section{$3 \cdot 2$ 試料片励振用ノズルの噴流力}

試料片励振用ノズルの噴流圧力とノズル背圧ならび に試験片との距離との関係をしらべるため，Fig.5の ような装置により実験を行なった。図で，平行 2 枚ば ね $\mathrm{P}$ は一端固定で自由端に油の粘性を利用したダンパ を有し，測定顕微鏡 $M_{\mathrm{c}}$ でその垂直変位を測定するこ そによりノズルからの噴流力が求められる，ノズルは
$2 \mu$ の微動目盛をもつステージにとりつけられていて 垂直変位が可能である.

実験方法としては，ノズル $\mathrm{N}_{1}{ }^{\prime}$ が平行ばねの上面に 密着した点を基準面とし，この位置よりノズルを上方 に移動させながら平行ばねの自由端の变位をよみとる ことにより，ノズルとその対向面との間隔と噴流力と の関係を求めた。な特，ノズルの背圧は精密減圧弁 $\mathrm{R}_{\mathrm{v}}$ と補助バイパス弁 $\mathrm{R}_{\mathrm{b}}$ の調整により所要の設定值 $p_{0}$ （一定）に保持されるようにした。

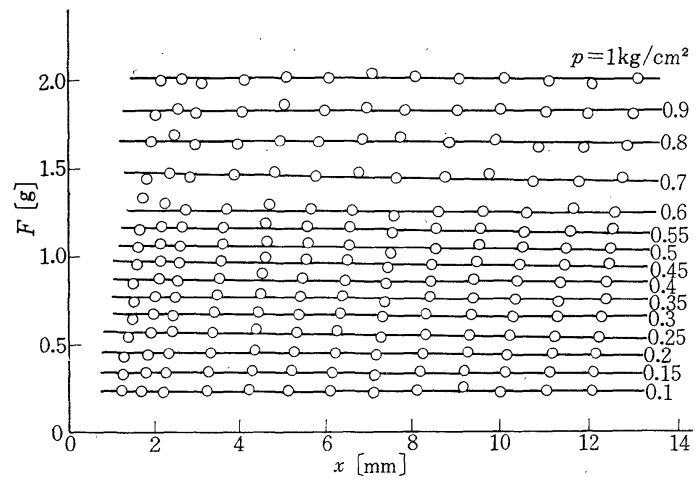

(a) in case of nozzle $\mathrm{N}-3$

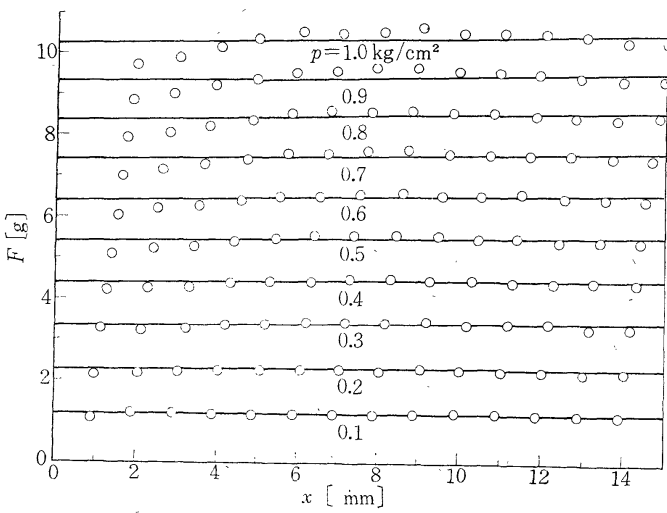

(b) in case of nozzle $\mathrm{N}-5$

$\mathrm{O}$ : experimental value - : theoretical value

Fig. 6 Impressing force $F$ from the exciting nozzle related with the gap $x$ between the nozzle and its counterface

実験は Table 1 に特ける N-3 の試料励振用ノズ ルの注か，バィアスカ加圧用のノズル N-5 について も行なった. Fig. 6 （a）は励振用ノズルについての もので，ノズル背圧をパラメータとし，ノズルとその 対向面との間隔 $x$ と噴流力 $F$ との関係を求めたもので ある.この実験結果より， $x=2 \sim 12 \mathrm{~mm}$.の範团で噴 流力 $F$ は背圧 $p$ に比例して増大し， $x$ に関してほぼ一 定とみなしらることがわかる，実験結果を各pについ て $x$ に対する直線であらわし，それらをまとめて全体 に適合する関係式を最小 2 乗法により求めると次式が 
得られる.

$$
F=(0.078+1.98 p)-p(0.013-0.009 p) x
$$

となる. (単位 $F: \mathrm{g}, p: \mathrm{kg} / \mathrm{cm}^{3}, x: \mathrm{mm}$ ) 図中の実 線はこれに基づいたものである。（11）式から（1）式 飞持沙る $\partial F / \partial p, \partial F / \partial x$ を求めると,

$$
\begin{aligned}
& \left(\frac{\partial F}{\partial x}\right)_{x}=-0.013 p+0.009 p^{2}(g / \mathrm{mm}) \\
& \left(\frac{\partial F}{\partial p}\right)_{p}=1.98-(0.013-0.018 p) x\left(g / \mathrm{kg} / \mathrm{cm}^{2}\right)
\end{aligned}
$$

となるが，実用的には（11）式の第 2 項は第 1 項にく らべて無視しうる程度であり， $\frac{\partial F}{\partial x} \doteqdot 0$ と考えてさし つか亲ない.つぎに Fig. 6 (b) は一定バイアスカ加 圧用ノズルの実験值で, 同様にして求めた曲線が併記 されている，この場合実験式は，

$$
\begin{aligned}
F= & 0.0925+11.1 p_{0}-0.91 p_{0}{ }^{2} \\
& -\left(0.0021-0.033 p_{0}+0.014 p_{0}{ }^{2}\right) x
\end{aligned}
$$

であり, $x=5 \sim 15 \mathrm{~mm}$ で背圧の調整により最大 $10.5 \mathrm{~g}$ $\left(p_{0}=1 \mathrm{~kg} / \mathrm{cm}^{2}\right)$ の噴流力を得ることができる.

\section{4. 応用結果とその検討}

この装置の有効性をしらべるため, 数種の試料を準 備し, 室温 $\left(20 \sim 22^{\circ} \mathrm{C}\right)$ に特ける弾性係数を $3 \cdot 1$ にの べた方式により求めた，Table 2 はこの結果で, 共振 時に特汓る試料の振動振幅が 2 3 $\mathrm{mm}$ 飞なるように してそのときの周波数を測定して得たものである. Table 2 飞は定数表よりの基準値が，また特に愿い No. 9 の試料について静的な Euing の方法による測 定結果が併記されているが，これらとの比較から測定 結果が妥当なるのであることがわかる. 試料の厚さの
不均一性や寸法測定の精度からいってこれらの実験値 の確度は $2 \%$ 程度であるが，共振周波数の測定精度な らびに再現性は $0.2 \%$ であり, 絶対精度を必要としな い目的には十分な実用性があると考光られる。なお， $0.3 \sim 0.1 \mathrm{~mm}$ の試料佗, Table 2 の No. 4, No. 5 の比較からも見られるよらに燐青銅のようなば 叔用材料に市っては幅の影響は $5 \mathrm{~mm}$ 以下で幽孔ば 特認められない。しかしながら測定が正確に行なわ れるためには，試料がわん曲していないこと特よび試 料が固定部で完全に固定されていることが必要である.

疲労試験を行なう場合, 試料を共振点の周波数で加 振する方法と, 共振点以外の周波数で加振する方法が 考兄ら机る. 前者に上れば試料を効率上く大振幅で励 振することが可能であるが, 試料の特性の経時変化な ぞのため長時間にわたって試料を同一振幅の共振状態 に保持することは一般に困難であって実用的でなく， 後者が用いられねばならない。試作装置の場合, 試料 を励振できる最高周波数は $60 \mathrm{~Hz}$ であるため, この周 波数で試料を励振するのが最も能率的である. したが って試験片の寸法を共振周波数がこの值よりやや高く なるように選ぶのがよいが, 試験片の形状寸法が定め られていて共振周波数が $60 \mathrm{~Hz}$ 以下之なる場合には， その共振周波数上りやや近い周波数で励振を行ならの が効果的である. Fig. 7 は励振ノズル N-3 を用いる として, 一様な幅で長方形断面の任意の試験片の振れ と作動圧の関係で, これを用いて必要な試験片の振れ 幅の概略值をあらかじめ定めることができる、Table

\begin{tabular}{|c|c|c|c|c|c|c|c|c|}
\hline No. & material & $\begin{array}{c}\text { thickness } \\
{[\mathrm{mm}]}\end{array}$ & $\begin{array}{l}\text { width } \\
{[\mathrm{mm}]}\end{array}$ & $\begin{array}{l}\text { length } \\
{[\mathrm{mm}]}\end{array}$ & $\begin{array}{l}\text { specific } \\
\text { weight } \\
{\left[\mathrm{g} / \mathrm{cm}^{3}\right]}\end{array}$ & $\begin{array}{c}\text { resonant } \\
\text { frequency } \\
{[\mathrm{Hz}]}\end{array}$ & $\begin{array}{l}\text { Young's modulus } \\
(\text { experimental }) \\
\left(\times 10^{3} \mathrm{~kg} / \mathrm{mm}^{2}\right)\end{array}$ & $\begin{array}{c}\text { Young's modulus } \\
\text { (physical table }) \\
\left(\times 10^{3} \mathrm{~kg} / \mathrm{mm}^{2}\right)\end{array}$ \\
\hline 1 & iron & 0.568 & 7.1 & 110.0 & 7.86 & 36.03 & 20.998 & 21.0 \\
\hline 2 & titan cupper & 0.487 & 2.7 & 80.0 & 8.84 & 45.78 & 12.117 & 12.0 \\
\hline 3 & phos. bronz (A) & 0.105 & 5.1 & 50.0 & 8.86 & 23.12 & 10.496 & 11.0 \\
\hline 4 & $" \quad(A)$ & 0.105 & 3.3 & 50.0 & " & 23.07 & 10. 464 & " \\
\hline 5 & (B) & 0.146 & 3.0 & 50.0 & 8.87 & 23.33 & 11.130 & " \\
\hline 6 & (C) & 0.189 & 3.3 & 70.0 & 8.90 & 20.87 & 11.014 & " \\
\hline 7 & (D) & 0.250 & 5 & 70.0 & 8.91 & 28.86 & 10.999 & " \\
\hline 8 & (E) & 0.305 . & 3.2 & 70.0 & 8.87 & 34.84 & 10.858 & " \\
\hline 9 & $" \quad(F)$ & 1.2 & 10 & 180.0 & 8.95 & 20.46 & 10.72 & $11.0\left(11.1^{*}\right)$ \\
\hline
\end{tabular}
3 は橉青銅の 2 個の試験片に対して, これを利用して 求めた振れ幅と実験値との比較である.

この装置は金属薄板の試験を目的として製作された

Table 2 Experimental results

\begin{tabular}{|c|c|c|c|c|c|c|c|}
\hline \multirow{2}{*}{ material } & \multirow{2}{*}{$\begin{array}{c}\text { thickness } \\
{[\mathrm{mm}]}\end{array}$} & \multirow{2}{*}{$\begin{array}{l}\text { width } \\
{[\mathrm{mm}]}\end{array}$} & \multirow{2}{*}{$\begin{array}{l}\text { length } \\
{[\mathrm{mm}]}\end{array}$} & \multirow{2}{*}{$\underset{\left[\mathrm{kg} / \mathrm{cm}^{2}\right]}{\text { operating range }}$} & \multirow{2}{*}{ value of $K$} & \multicolumn{2}{|c|}{ amplitude $[\mathrm{mm}]$} \\
\hline & & & & & & experimental & estimated \\
\hline phos. bronz & 0.305 & 5.4 & 68.0 & $0.19 \sim 0.3$ & $1.86 \times 10^{2}$ & $0.48 \sim 0.51$ & 0.5 \\
\hline$"$ & 0.305 & 5.4 & 68.0 & $0.34 \sim 0.76$ & $1.86 \times 10^{2}$ & $1.16 \sim 1.19$ & 1.18 \\
\hline$"$ & 0.105 & 5.1 & 48.5 & $0.16 \sim 0.31$ & $1.753 \times 10^{3}$ & $4.3 \sim 4.6$ & 4.2 \\
\hline
\end{tabular}

* experimental value by Euing's method

Table 3 Comparison between the experimental amplitude of vibration of specimen and the estimated one based on Fig. 7 


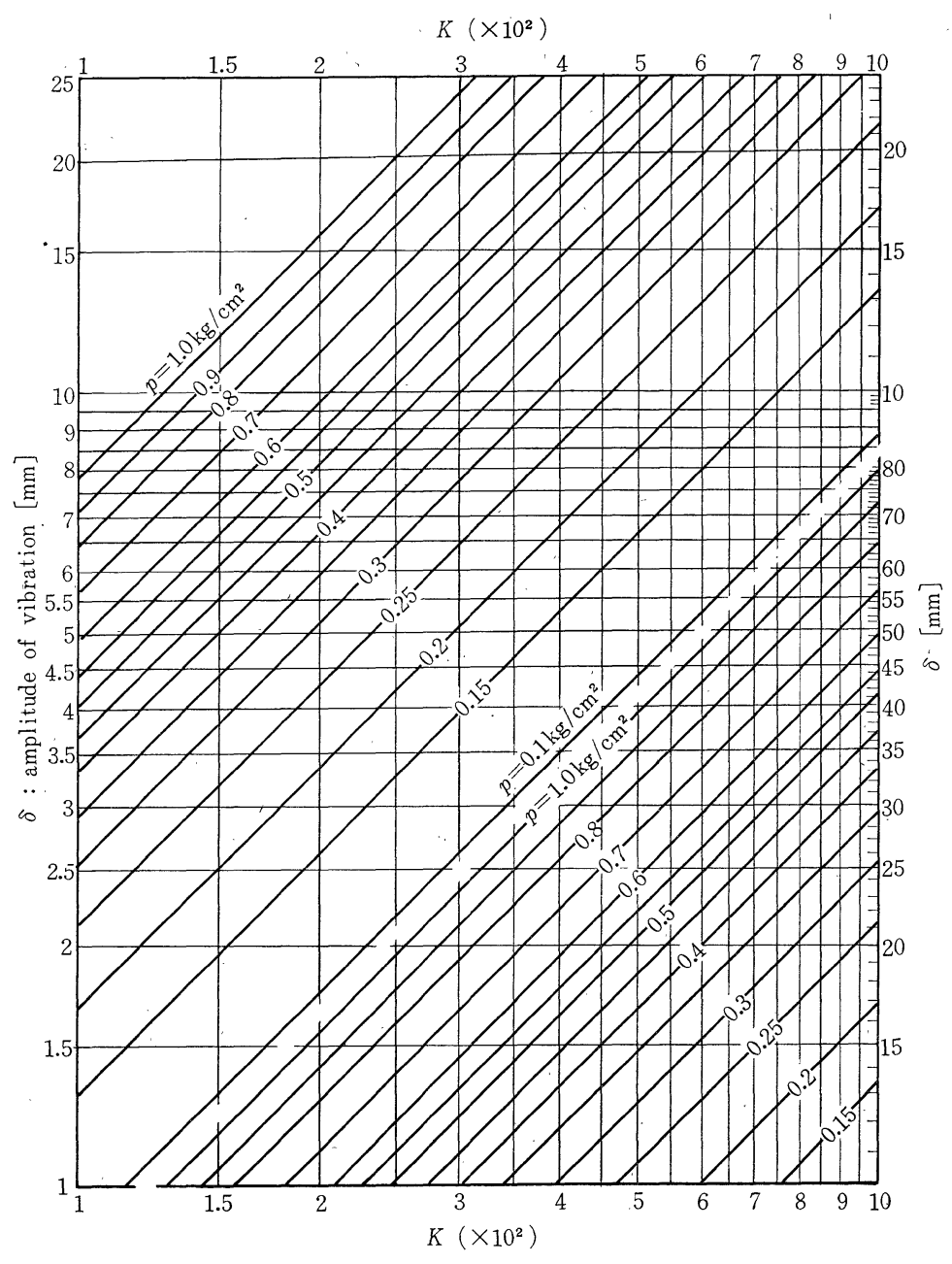

gap between nozzle and specimen $=6 \sim 12 \mathrm{~mm}$,

specimen : with rectangular section, equal width : $\left.K=\left(\frac{l^{3}}{b h^{3} E}\right) / K_{0} \quad \begin{array}{l}l: \text { length of specimen, } b: \text { width, } h: \text { thichness, } \\ E: \text { Young's modulus, } K_{0}=1.0 \mathrm{~mm} / \mathrm{kg}\end{array}\right)$

Fig. 7 A diagram to estimate for vibration amplitude of specimen with nozzle $\mathrm{N}-3$

Table 4 Experimental results applied to non-metalic materials

\begin{tabular}{l|c|c|c|c|c}
\hline \multicolumn{1}{c|}{ material } & $\begin{array}{c}\text { thickness } \\
{[\mathrm{mm}]}\end{array}$ & $\begin{array}{c}\text { width } \\
{[\mathrm{mm}]}\end{array}$ & $\begin{array}{c}\text { length } \\
{[\mathrm{mm}]}\end{array}$ & $\begin{array}{c}\text { specific } \\
\text { weight } \\
{\left[\mathrm{g} / \mathrm{cm}^{3}\right]}\end{array}$ & $\begin{array}{c}\text { resonant } \\
\text { frequency } \\
{[\mathrm{Hz}]}\end{array}$ \\
\hline drawing paper & 0.242 & 12.0 & 70.0 & 0.855 & 1.997 \\
photographic paper & 0.248 & 12.0 & 70.0 & 1.084 & 2.466 \\
Japanese paper & 0.227 & 12.0 & 67.5 & 0.672 & 2.137 \\
photographic film & 0.130 & 12.0 & 50.0 & 1.342 & 1.517 \\
polyester & 0.067 & 12.0 & 70.0 & 1.331 & 0.311 \\
vinyl chloride & 0.97 & 5.0 & 70.0 & 1.386 & 4.976 \\
\hline
\end{tabular}

るが，これらの観測值が金属の ヤング率に相当する “こしの強 さ”に対応することを利用して， これら軟質材料の試験研究に応 用することが考光られる、な执, これらの実験にさいして, 試料 の振動状況はかなり鋭い共振特 性を示した。

\section{4. 結言}

以上のべたことを要約すると 以下のよらになる。

1）傾斜円盤の回転と，その 直径上に近接して取りつけた 2 つのノズルにより発振した正弦 波状空気圧を，別に設けた対称 に配置されたノズルの 1 組に導 いて薄板状試料に励振力をあた える機構について提案した，2) 実験装置によりその主要部の特 性（発振回路の静特性之動特性。 ノズル背圧と励振力との関係） についてしらべ検討を行なった。 3）試作装置を使用して各種金 属試験片の弾性係数を測定し, その有効性を確かめた。

この装置は金属試料の弾性特 性試験を目的として製作された ものであるが, 試験片の材質に よらずそのままの状態で試験が 可能であるため, せんい, プラ スチック，ファイバーなどの軟 質材料の可撓性試験, 疲労試験 などへ幅広い応用が可能である と思われる。

\section{参考文 献}

1) JIS H 3801-1966 片持はり式 ばね限界值測定法

2) DIN-50151 Federblech Biegeversuch mit Feinmessung

3) Measuring the thermoelastic coefficient of metallic diaphragm materials H.R. Holmes

4）梅川：片持横振動による弾性 係数の測定について, 機械学 会論文集，19-84，111/115 (1953)

5) R. M. Davies \& I. Thomas : A Dynamical Method for the Measurement of Young's Modulus for Imperfectly Elastic Metals, and application of the $\mathrm{Me}$ thod to Nickel and some of its Alloys. Phil. Mag. S.7,

23-154, 361/397 (1937)

6) F. Kohlrausch : Praktische Physik, F. Henning, 94 (1935)

7）山本：傾斜円盤を利用した空気的信号発生機とその応 用，計測と制御，2-12，988/993 (1963)

薄板片試料に対して共振周波数を求めた実験結果であ 